\title{
THE ASSOCIATIONS BETWEEN AGE, STRESS, HIGH PURINE DIET, AND URIC ACID LEVEL
}

\author{
Dewi Wulandari \\ Diploma Program in Nursing, Bhakti Mulia Health Polytechnics, \\ Sukoharjo, Central Java
}

\begin{abstract}
Background: Gout is the most prevalent form of inflammatory arthropathy. The Indonesian Basic Health Research (RISKESDAS) reported that gout prevalence in Indonesia in 2013 was $11.9 \%$ based on health professional diagnosis, or $24.7 \%$ based on sign and symtomps. Numerous risk factors for the development of gout have been established, including hyperuricaemia, genetic factors, dietary factors, alcohol consumption, metabolic syndrome, hypertension, obesity, diuretic use, and chronic renal disease. However, limited studies have been conducted on the psychological risk factors. This study aimed to determine the associations between age, stress, high purine diet, and uric acid level.

Subjects and Method: This was a cross-sectional study conducted in Sukoharjo, Central Java. A sample of 72 study subjects was selected by simple random sampling. The dependent variable was uric acid level. The independent variables were age, stress, and high purine diet. Stress was measured by Depression, Anxiety, and Stress Scale (DASS 42). Uric acid level was measured by uric acid meter. The other variables were collected by questionnaire. The data were analyzed by a multiple linear regression.

Results: Uric acid level increased with age $(b=0.07 ; 95 \% \mathrm{CI}=0.03$ to $0.10 ; \mathrm{p}<$ 0.001), stress $(b=0.07 ; 95 \% \mathrm{CI}=0.02$ to $0.12 ; \mathrm{p}<0.01)$, and high purine diet $(\mathrm{b}=$ $0.26 ; 95 \% \mathrm{CI}=0.14$ to $0.39 ; \mathrm{p}<0.001)$.

Conclusion: Uric acid level increases with age, stress, and high purine diet.
\end{abstract}

Keywords: uric acid, purine-rich food intake, age, stress

\section{Correspondence:}

Dewi Wulandari. Diploma Program in Nursing, Bhakti Mulia Health Polytechnics, Sukoharjo, Central Java, Jl. Raya Solo-Sukoharjo KM. 9, Bendosari, Sidorejo, Bendosari, Sukoharjo 57551, Jawa Tengah.

Email: hani_wulan84@yahoo.co.id.

Mid-International Conference on Public Health, Best Western Premier Hotel, Solo, Indonesia, 18-19 April 2018 | 257 https://doi.org/10.26911/mid.icph.2018.05.19 